\title{
Low-Density Insulation Blocks and Hardboards from Amaranth (Amaranthus cruentus) Stems, a New Perspective for Building Applications
}

\author{
Philippe Evon ${ }^{1, *} \mathbb{C}$, Guyonne de Langalerie ${ }^{1,2}$, Laurent Labonne ${ }^{1}$, Othmane Merah ${ }^{1,3}{ }^{\mathbb{C}}$, Thierry Talou ${ }^{1}$, \\ Stéphane Ballas ${ }^{2}$ and Thierry Véronèse ${ }^{2}$ \\ 1 Laboratoire de Chimie Agro-Industrielle (LCA), Université de Toulouse, ENSIACET, INRAE, Toulouse INP, \\ 4 allée Emile Monso, 31030 Toulouse, France; guyonne.delangalerie@gmail.com (G.d.L.); \\ Laurent.Labonne@ensiacet.fr (L.L.); othmane.merah@ensiacet.fr (O.M.); Thierry.Talou@ensiacet.fr (T.T.) \\ 2 Ovalie Innovation, 2 rue Marguerite Duras, 32000 Auch, France; \\ stephane.ballas@ovalie-innovation.com (S.B.); thierry.veronese@ovalie-innovation.com (T.V.) \\ 3 Département Génie Biologique, IUT A, Université Paul Sabatier, 24 rue d'Embaques, 32000 Auch, France \\ * Correspondence: Philippe.Evon@ensiacet.fr; Tel.: +33-(0)562-446080
}

check for updates

Citation: Evon, P.; de Langalerie, G.; Labonne, L.; Merah, O.; Talou, T.; Ballas, S.; Véronèse, T. Low-Density Insulation Blocks and Hardboards from Amaranth (Amaranthus cruentus) Stems, a New Perspective for Building Applications. Coatings 2021, 11, 349. https://doi.org/10.3390/ coatings11030349

Academic Editor: Yong X. Gan

Received: 23 February 2021

Accepted: 15 March 2021

Published: 18 March 2021

Publisher's Note: MDPI stays neutral with regard to jurisdictional claims in published maps and institutional affiliations.

Copyright: (c) 2021 by the authors. Licensee MDPI, Basel, Switzerland. This article is an open access article distributed under the terms and conditions of the Creative Commons Attribution (CC BY) license (https:// creativecommons.org/licenses/by/ $4.0 /)$.

\begin{abstract}
Nowadays, amaranth appears as a promising source of squalene of vegetable origin. Amaranth oil is indeed one of the most concentrated vegetable oils in squalene, i.e., up to $6 \%(w / w)$. This triterpene is highly appreciated in cosmetology, especially for the formulation of moisturizing creams. It is almost exclusively extracted from the liver of sharks, causing their overfishing. Thus, providing a squalene of renewable origin is a major challenge for the cosmetic industry. The amaranth plant has thus experienced renewed interest in recent years. In addition to the seeds, a stem is also produced during cultivation. Representing up to $80 \%(w / w)$ of the plant aerial part, it is composed of a ligneous fraction, the bark, on its periphery, and a pith in its middle. In this study, a fractionation process was developed to separate bark and pith. These two fractions were then used to produce renewable materials for building applications. On the one hand, the bark was used to produce hardboards, with the deoiled seeds acting as natural binder. Such boards are a viable alternative to commercial wood-based panels. On the other hand, the pith was transformed into cohesive and machinable low-density insulation blocks revealing a low thermal conductivity value.
\end{abstract}

Keywords: amaranth stem; bark; pith; insulation blocks; hardboards

\section{Introduction}

Amaranthus cruentus is an annual herb native to temperate and tropical regions. It is cultivated for the nutritional properties of its seeds [1-3]. It is a promising raw material as all parts are potentially usable for both food and non-food applications.

The amaranth seed contains a lipid fraction $(7-8 \%)$, rich in squalene of vegetal origin (5-6\%) [4]. Acting as an essential intermediate in the biosynthesis of cholesterol, steroid hormones, and vitamin D for humans, squalene is a triterpene largely used as food supplement or for cosmetics [5]. In particular, squalene is used in pharmaceutical and especially in cosmetic formulations for the treatment of skin disorders because of its moisturizing and protective activity against external agents, e.g., air, light, UV rays, environmental pollution, etc. [6]. It is a good emollient, and the cosmetic industry uses it especially for the manufacture of moisturizers, make-up, lipstick, and hair care products. Besides squalene, its hydrogenated product, squalane, is even often preferred to squalene as it has a greater oxidation stability, due to the absence of double bonds [7].

The amaranth seed also contains a substantial amount of proteins (15\%). The latter could be used for bread flours as a protein reinforcement [8], and for their biocidal and antioxidant activities [9]. In addition, they would be potentially usable for their emulsifying 
capacity (surfactants for food or in cosmetic creams) [10] or for their adhesive properties in the panel industry [11-13].

Lastly, the amaranth seed is particularly rich in starch (up to 55\%). After its plasticization/gelatinization (plus the denaturation of proteins) through a thermo-mechano-chemical pre-treatment using the twin-screw extrusion technology, amaranth seed (or cake) could thus be possibly transformed into thermoplastic granules for injection-molding applications $[14,15]$.

During amaranth cultivation, a stem is also produced. Representing up to $80 \%(w / w)$ of the plant aerial part, it is composed of a pith fraction in its middle, and a bark (i.e., a woody part, or ligneous fraction) on its periphery. To our knowledge, the scientific literature does not refer to works that have already used the amaranth stem in the manufacture of bio-based materials, particularly for construction applications. Nevertheless, the use of natural fibers (or aggregates) in composites as a replacement for mineral fillers or glass or carbon fibers has many advantages. Especially, composites made from natural by-products are highly recyclable, environmentally friendly, cost-effective, and also safe for society. By way of an example, flax and jute fibers have already shown their full potential for the reinforcement of an acrylic resin, the obtained composites being usable in the automotive sector [16]. In addition, with a pith in its middle and a bark on its periphery, the structure of the amaranth stem is close to that of sunflower, which is already used in the building sector. For these different reasons, it is reasonable to assume that the pith and bark particles from the amaranth stem could also be used for the manufacture of bio-based building composite materials, thus providing real benefits for the near future.

Firstly, pith particles reveal an alveolar structure close to that of expanded polystyrene. The same was true for the pith fraction coming from sunflower stem [17], and this has recently allowed the development of sunflower-based low-density insulation materials for buildings [18-20]. The construction sector generates major environmental impacts, e.g., consumption of non-renewable raw materials, greenhouse gas (GHG) emissions, waste production, etc. [21]. Numerous research projects are therefore currently aimed at developing alternative materials with low environmental costs. In particular, the use of plant co-products in building materials is particularly interesting. Indeed, vegetable aggregates are renewable. They are mainly produced locally, and they also constitute a carbon sink.

In this topic, a low-density insulation block consisting solely of sunflower pith particles and a starch-based glue was recently developed [20]. Its good mechanical resistance allowed machining. In addition, its thermal insulating ability in dry state $(32 \mathrm{~mW} /(\mathrm{m} . \mathrm{K})$ at $25^{\circ} \mathrm{C}$ ) was equivalent to those of stone wool and expanded polystyrene, therefore corresponding to current standards for heat transfer. However, while the thermal conductivity of expanded polystyrene was not affected by ambient humidity, that of the sunflowerbased samples increased by about $15 \%$ (i.e., reduced insulating properties), which was explained by the highly hygroscopic nature of these bio-based materials. Conversely, the latter revealed a high water vapor permeability (i.e., five to ten times higher than expanded polystyrene). Their power as water regulators could be useful in houses to regulate indoor humidity variation. For example, the risk of condensation at the interface between different layers of materials could be limited, and this could be useful in the case of the renovation of old buildings [20].

A more recent improvement has been the application of a surface treatment made of glycerol esters to make these sunflower-based insulation blocks more resistant to microbial growth [22]. Even in the presence of the glycerol esters, the potential of the light insulation made of sunflower pith was highlighted, with a $50 \mathrm{~kg} / \mathrm{m}^{3}$ density and a $35 \mathrm{~mW} /(\mathrm{m} . \mathrm{K})$ thermal conductivity at $25^{\circ} \mathrm{C}$. Its high water vapor permeability was also preserved. The antimicrobial efficiency of glycerol esters was evidenced, contributing to better protection of these bio-based materials from microbial proliferation. At the same time, a non-flammability classification has been surprisingly assigned to the untreated insulation materials. 
On its side, the amaranth bark reveals a high amount of lignocellulosic fibers. Such a characteristic could allow its use as a mechanical reinforcement inside biocomposites, in particular injection-moldable materials [23,24] or fiberboards (e.g., hardboards). For this second purpose, the bark pre-treatment through twin-screw extrusion-refining could make this reinforcement capability even more important, thanks to an improvement in the morphological characteristics of the fibers (i.e., increase in their mean aspect ratio, defined as the ratio of the length to the diameter, after refining).

The twin-screw extrusion technology has already proven itself in the processing of biomass, including mechanical pressing of vegetable oil from various oilseeds, continuous liquid/solid extraction of active biomolecules, starch plasticization, protein destructurization and denaturation, compounding of matrix/fiber type thermoplastic granules, production of second-generation bioethanol, etc. $[25,26]$. Especially, it has also recently been used as an alternative tool for the thermo-mechanical defibration of various agricultural by-products or those resulting from a first agro-industrial transformation such as rice straw $[27,28]$, coriander straw [13,29], oleaginous flax shives [30,31], and sunflower bark [22], prior to hot pressing.

The function of defibration is to break down the lignins that protect cellulose and hemicelluloses. This pre-treatment contributes to increase the fiber-specific surface and to promote their self-adhesion [30]. The applied pre-treatments are most often mechanical, thermal, and/or chemical ones [32]. As a first non-expensive solution, a simple grinding enables the improvement of the particle size profile of micrometric fibers [30,33,34]. Defibration is however much more efficient when thermo-mechanical pulps are produced. Widely used in the paper industry, the thermo-mechanical defibration can be carried out from different pulping processes [35], including digestion plus defibration [36] and steam explosion [37-41]. More original pre-treatment methods involving enzymes have also been considered [42-44]. However, they have the disadvantage of being rather difficult to implement on a large scale.

Twin-screw extrusion, on the other hand, can be more easily deployed in the industry. Above all, it has recently shown its full potential for an efficient thermo-mechanical defibration of lignocellulosic by-products at a moderate cost. It was compared with a digestion plus defibration process from the paper industry for the pre-treatment of rice straw [27]. A significantly reduced cost (i.e., nine times less) was observed for the extrusion-refining process. In parallel, this technology was much more efficient, even with reduced amount of water added (i.e., $0.4-1.0$ instead of at least 4.0 in the case of the pulping method), as the length of the refined fibers was better preserved using the extrusion-refining process: 21.2-22.6 for their average aspect ratio instead of 16.3-17.9 in the case of the digestion plus defibration process. With such significantly improved mechanical reinforcement capability, the extrusion-refined rice straw thus enabled the manufacture of fiberboards with particularly promising usage properties [28]. The optimal one was molded after the addition of $8.9 \%(w / w)$ commercial Biolignin ${ }^{\mathrm{TM}}$ (i.e., a pure and non-deteriorated Organosolv lignin extracted from wheat straw using a mixture of acetic acid and formic acid) as a binder. With a density of $1414 \mathrm{~kg} / \mathrm{m}^{3}$, the latter revealed very high bending properties (i.e., strength at break and elastic modulus of $50 \mathrm{MPa}$ and $8.6 \mathrm{GPa}$, respectively), simultaneously with good water resistance (i.e., thickness swelling and water absorption of $24 \%$ and $18 \%$, respectively, after $24 \mathrm{~h}$ soaking in water). Such a rice straw-based material could be used as a load-bearing board under high stress.

Another recent study focused on the extrusion-refining of coriander straw [13]. The results obtained during this study confirmed the interest of the twin-screw extrusion pre-treatment with regard to the average aspect ratio of the obtained fibres, which was evaluated at values of between 22.9 and 26.5 depending on the amount of water added during extrusion, as opposed to only 4.5 in the case of a straw that was simply crushed using a hammer mill. During this study, fiberboards combining the straw as a reinforcement and the cake resulting from the extraction of vegetable oil from the coriander seeds as a protein binder were manufactured through hot pressing. All biocomposites made of the 
extrusion-refined coriander fibers have shown better usage properties, and the optimal $100 \%$ coriander-based board was the one containing $40 \%(w / w)$ cake. The latter had the next characteristics: $1195 \mathrm{~kg} / \mathrm{m}^{3}$ density, $29.1 \mathrm{MPa}$ flexural strength at break, $3.9 \mathrm{GPa}$ elastic modulus, $24 \%$ thickness swelling, and $24 \%$ water absorption. Less dense and with lower bending properties than the optimal hardboard developed by Theng et al. from rice straw [28], it still had a water resistance after $24 \mathrm{~h}$ immersion of the same order of magnitude, thanks to a heat post-treatment applied after hot pressing. Its bending properties were nonetheless sufficient to use it in dry conditions, for general purposes (e.g., carcasses, domestic flooring, etc.) as well as furniture grade and load-bearing board (e.g., shelving). Additionally, the VOC and carbonyl compound emissions from this hardboard were studied, and no formaldehyde emission was detected [29]. In comparison with most of the wood-based materials available on the market (e.g., medium-density fiberboard (MDF) or chipboard, which have also been tested in that study), it was thus more environmentally and human-health friendly.

A single twin-screw extruder can even be used both as a continuous fiber-refining tool and as a tool for adding continuously an exogenous binder to the previously refined fibers, resulting at the extruder outlet in an homogeneous premix made of reinforcing fibers and a binder, ready to be transformed into cohesive fiberboards through hot pressing [13,31].

In respect with the biorefinery concept of whole plants, this study aimed to develop a continuous mechanical process allowing the fractionation of the amaranth stem into bark and pith, and to investigate the use of those two fractions for building material applications. Two families of innovative bio-based materials were investigated, i.e., bulk (loose fill) insulation and low-density blocks from the pith fraction on the one hand, and hardboards from the bark fraction on the other hand. The use as a natural binder of the solid residue (i.e., the cake) obtained after extraction of vegetable oil from the amaranth seeds using an apolar solvent was also investigated in this study, due to its natural richness in proteins and especially starch.

\section{Materials and Methods}

\subsection{Raw Materials and Natural Binders}

The amaranth (Amaranthus cruentus) stems and seeds used in this study were from the South-West part of France. They were cultivated near the city of Auch during the summer of 2018. They were supplied by Ovalie Innovation (Auch, France).

The starch-based binder used for producing the low-density insulation blocks had an $85 \%(w / w)$ starch content. Supplied by Bostik (Colombes, France) with reference number 28474 , it is usually used as a glue for wallpapers.

The amaranth-based binder $(\mathrm{AB})$ used for obtaining the hardboards was prepared from the seeds supplied by Ovalie Innovation. Firstly, the latter were grinded using a Foss (Hilleroed, Denmark) Cyclotec 1093 sample mill fitted with a $1 \mathrm{~mm}$ screen. Deoiling was then conducted using a Soxhlet extraction apparatus (Lenz Laborglas, Wertheim, Germany), and cyclohexane as extracting solvent.

\subsection{Analytical Methods}

Mineral content inside amaranth pith and bark were determined according to the ISO 749:1977 standard [45]. An estimation of the three parietal constituents, i.e., cellulose, hemicelluloses, and lignins, was made from the ADF-NDF (ADF, Acid Detergent Fiber; NDF, Neutral Detergent Fiber) method of Van Soest and Wine [46,47]. The water-soluble components were determined by measuring the mass loss of the test sample after $1 \mathrm{~h}$ in boiling water. All determinations were made in triplicate.

\subsection{Grinding of Amaranth Stems and Separation between Bark and Pith Particles}

The grinding of amaranth stems was done using an Electra (Poudenas, France) Goulu $\mathrm{N}$ hammer mill with no grid. The separation between bark and pith particles was then conducted using a vacuum cleaner. The suction step was repeated three times, first on a 
Ritec 600 (Signes, France) vibrating sieve shaker and then twice on a rough and inclined conveyor belt.

During the initial sieving stage, the sieve shaker was fitted with two sieves with a mesh of $2 \mathrm{~mm}$ and $1 \mathrm{~mm}$, respectively, from top to bottom. Three different fractions made of dense bark particles were thus generated, i.e., fines $(<1 \mathrm{~mm})$, and medium (from 1 to $2 \mathrm{~mm}$ ) and large particles ( $>2 \mathrm{~mm}$ ). Additionally, thanks to the vacuum cleaner positioned above the upper sieve, the light pith particles were sucked continuously.

The three bark fractions collected at the level of the sieve shaker were almost pure. On the opposite, the pith one still contained some bark impurities, which were sucked simultaneously with the pith particles. Two additional purification extra-steps were thus required. The latter were conducted using an inclined conveyor belt made of a rough rubber band. A ventilator with an air speed from 1.0 to $2.5 \mathrm{~m} / \mathrm{s}$ was positioned at $1.3 \mathrm{~m}$ from the bottom of the conveyor belt, and the vacuum cleaner at its bottom. The movement of the conveyor belt was at constant speed, from bottom to top.

The pith fraction to be purified was fed at a constant mass flow rate onto the conveyor belt just in front of the ventilator. In doing so, the ventilation opposed the movement of the conveyor belt, and this allowed the pith particles, which were light and rather cylindrical in shape, to roll down to the bottom of the device where they were sucked. The bark particles to be removed, on the other hand, were much denser and had an elongated shape, so that they remained attached to the rough surface of the rubber band. They could then be picked up from the top of the device. In order to obtain a pith fraction with a purity of more than $90 \%(w / w)$, two successive passes of the pith on the conveyor belt were necessary, using an angle of inclination equal to $32^{\circ}$ and $23^{\circ}$, respectively.

In Figure 1, a schematic diagram of the fractionation process of the amaranth stems, including their grinding and then their separation between bark and pith particles through three successive suction stages, is presented. This diagram also includes the building materials obtained from each of these two fractions and the equipment used to obtain them.

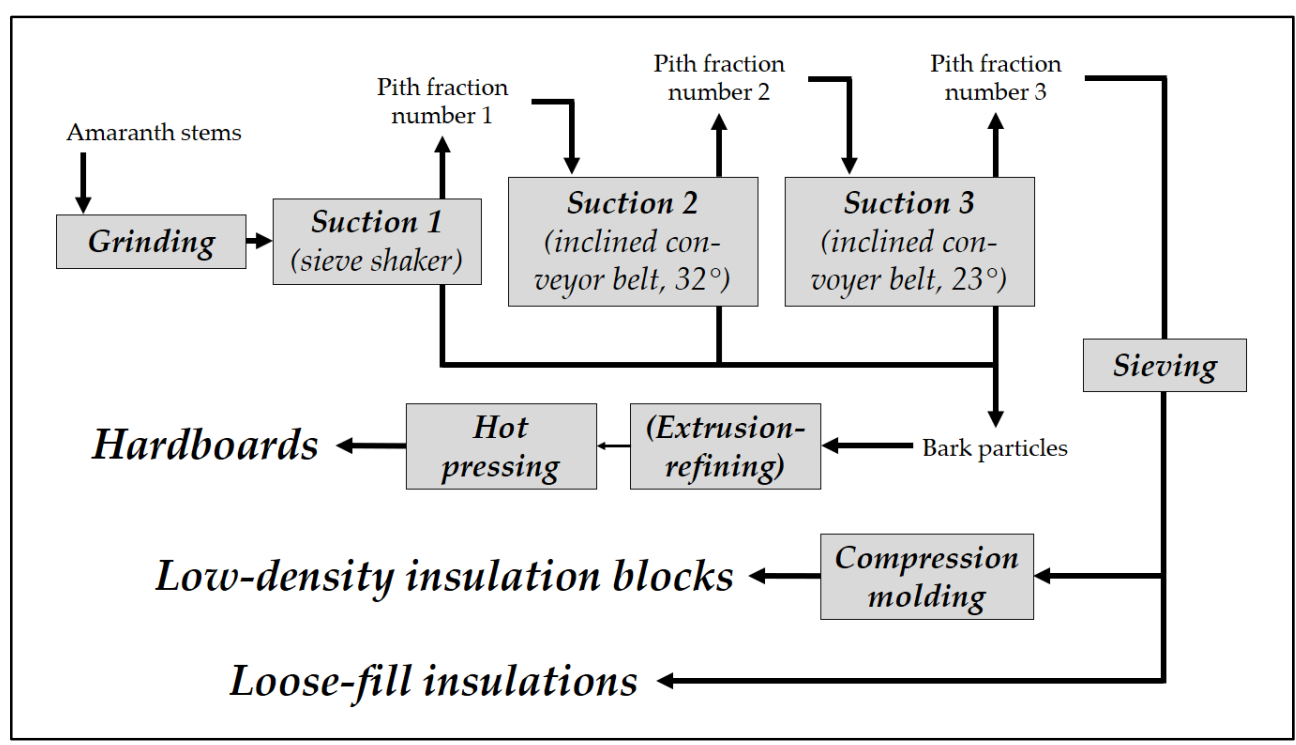

Figure 1. Schematic diagram of the fractionation process of the amaranth stems into bark and pith fractions, and building materials obtained from these fractions.

\subsection{Sieving of Pith Particles}

To determine the particle size distribution of the pith particles, a Retsch AS 300 (Haan, Germany) vibratory sieve shaker was used. The three implemented sieves had a mesh of $4 \mathrm{~mm}, 2 \mathrm{~mm}$ and $1 \mathrm{~mm}$, respectively, from top to bottom. A sieve acceleration of $1.5 \times \mathrm{g}$ and a sieving time of $10 \mathrm{~min}$ were chosen for sieving. 


\subsection{Twin-Screw Extrusion-Refining of Fibers from Amaranth Bark}

Amaranth bark particles with a diameter of more than $2 \mathrm{~mm}$ and a moisture content of $6.0 \pm 0.0 \%$ were extrusion-refined in the presence of water using a Clextral (Firminy, France) Evolum HT 53 co-rotating and co-penetrating twin-screw extruder. The screws were $53 \mathrm{~mm}$ in diameter (D), and the barrel was $36 \mathrm{D}$ in length with nine successive modules, each $4 \mathrm{D}$ in length.

The thermo-mechanical fiber pre-treatment was inspired by a previous work developed from the coriander straw [13]. Amaranth bark was fed using a weight dosing device in module 1 , and water was injected using a piston pump at the end of module 2 . In particular, to prevent water from clogging the twin-screw extruder, a filtration module equipped with two filter grids made of $1 \mathrm{~mm}$ diameter holes was positioned at the end of the barrel, i.e., in penultimate position. The excess of water was thus removed (in the form of an aqueous filtrate).

The screw profile used was that of Uitterhaegen et al. [13]. In particular, two successive pairs (i.e., $2 \mathrm{D}$ in length) of $\mathrm{BB}$ bilobe paddles mounted in a staggered pattern (i.e., with a $90^{\circ}$ angle) were positioned in module 5 to ensure intimate mixing and homogenization of solid and liquid phases. In addition, four successive pairs (i.e., 1.5 D in length) of CF1C screws (i.e., conjugated cut-flight, single-flight screws with left-handed pitch) were positioned at the beginning of module 9 . Thanks to the intense mechanical shear applied to the raw material in this location, this enabled an efficient extrusion-refining of fibers in amaranth bark.

The temperature profile used was as follows: $25^{\circ} \mathrm{C}$ for module 1 (feeding module), $50{ }^{\circ} \mathrm{C}$ for module $2,80^{\circ} \mathrm{C}$ for module $3,100^{\circ} \mathrm{C}$ for modules 4 to 7 , and $110{ }^{\circ} \mathrm{C}$ for module 9 (thermo-mechanical refining module).

The screw rotation speed was $250 \mathrm{rpm}$. The inlet flow rate of amaranth bark particles was $10 \mathrm{~kg} / \mathrm{h}$. Three different inlet flow rates of water were tested (i.e., $10 \mathrm{~kg} / \mathrm{h}, 20 \mathrm{~kg} / \mathrm{h}$ and $40 \mathrm{~kg} / \mathrm{h}$, respectively), corresponding to liquid/solid ratios of 1,2 , and 4 , respectively.

\subsection{Molding of Insulation Blocks and Hardboards}

The compression molding of the insulation blocks was conducted at room temperature inside an aluminium mold with $15 \mathrm{~cm}$ sides using a conventional hydraulic press. A pressure of $9 \mathrm{kPa}$ was applied at room temperature for $5 \mathrm{~min}$ to the mixture composed of pith particles (bulk test sample volume equal to $\left.2700 \mathrm{~cm}^{3}\right)$, starch-based binder $(10 \%(w / w)$ in proportion to the sum of the pith and binder masses), and water $(3.7 \%(w / w)$ for the binder to water ratio). For the medium size $(2-4 \mathrm{~mm})$ of pith particles only, starch-based binder contents of $15 \%, 20 \%$ and $25 \%(w / w)$ were also tested.

Once molded, the insulation blocks were dried at $60^{\circ} \mathrm{C}$ in a France Etuves (Chelles, France) XL2520 ventilated oven until constant weight (i.e., mass variation less than $0.1 \%$ after $24 \mathrm{~h}$ ). The drying step was conducted with the objective to eliminate the water added to dissolve the binder. As the external starchy binder used was with physical curing, the adhesion was achieved as water evaporated.

The hot pressing of hardboards was conducted using 400 tons capacity Pinette Emidecau Industrie (Chalon-sur-Saône, France) heated hydraulic press. The conditions were standard ones $[13,30]$, i.e., $200^{\circ} \mathrm{C}$ for the mold temperature, $20 \mathrm{MPa}$ for the applied pressure, and $5 \mathrm{~min}$ for the molding time.

A $150 \mathrm{~mm} \times 150 \mathrm{~mm}$ aluminium mold was used to perform both compression molding and hot pressing. The material thickness was $4 \mathrm{~cm}$ and around $4.5 \mathrm{~mm}$, respectively, for the insulation blocks and hardboards. All materials were then equilibrated in a climatic chamber at $60 \%$ relative humidity $(\mathrm{RH})$ and $25^{\circ} \mathrm{C}$ until constant weight (i.e., mass variation less than $0.1 \%$ after $24 \mathrm{~h}$ ). The equilibration lasted around three weeks, after which the materials were analyzed. 


\subsection{Density Measurements}

The bulk density of the pith and bark particles was measured using a $2 \mathrm{~L}$ test tube. Once filled with the particles, the latter were weighed in order to determine the bulk density. The tapped density of bark particles, before and after the extrusion-refining step, was determined using a Granuloshop (Chatou, France) Densitap ETD-20 volumenometer. All determinations were carried out in triplicate.

The density of the insulation blocks and hardboards was conducted from the bending test specimens. An electronic digital sliding caliper having a resolution of $0.01 \mathrm{~mm}$ was used to measure their thickness, width, and length, allowing the specimen volume to be calculated. In parallel, all the test specimens were also weighed, enabling their density to be determined. All determinations were carried out four times.

\subsection{Physical Characterization of the Building Materials}

The flexural properties of the insulation blocks and hardboards were measured using the three points bending technique according to the ISO 16978:2003 standard [48]. The universal testing machine used for those tests was an Instron (Norwood, MA, USA) 5500R machine fitted with a $500 \mathrm{~N}$ load cell. All test specimens were $3 \mathrm{~cm}$ wide, and $12 \mathrm{~cm}$ long. The grip separation was $8 \mathrm{~cm}$, and the test speed was $2 \mathrm{~mm} / \mathrm{min}$. All determinations were conducted four times.

The thermal conductivity of loose pith particles and insulation blocks was measured at $25{ }^{\circ} \mathrm{C}$ using a Neotim (Albi, France) FP2C thermal conductivimeter with a hot wire. A $5 \%$ accuracy was obtained for these measurements. During the hot wire test, an electric current through the linear wire generated heat, which resulted in the increase of the temperature of the material tested. The wire length was considered as infinite, and its diameter as negligible. The wire and thermocouple were included in a Kapton probe. During the test, the probe was placed in the middle of the pith particles arranged in bulk, or between two samples of the insulation block. As the material tested was considered as semi-infinite, the heat conduction equation was solved in cylindrical coordinates. This allowed the determination of the thermal conductivity. Then, the thermal resistance was deduced from the thermal conductivity value by considering a $4 \mathrm{~cm}$ thickness for the loose pith particles as for the insulation blocks. Before the test, the pith particles were equilibrated in a climatic chamber under the same conditions as those used for the insulation blocks, i.e., $60 \% \mathrm{RH}$ and $25^{\circ} \mathrm{C}$ for three weeks. All determinations were conducted in triplicate.

The thickness swelling of hardboards was measured after $24 \mathrm{~h}$ immersion in water according to the ISO 16983:2003 standard [49]. Expressed in mass percentage, their water absorption level was determined at the same time. All determinations were conducted four times.

\subsection{Statistical Analyses}

Results are expressed as mean value \pm standard deviation. One-way analysis of variance (ANOVA) was used in order to examine the significance of the effect of factors on studied traits. Duncan's multiple range test was used to compare individual means at a 5\% probability level.

\section{Results}

\subsection{Separation between Pith and Bark}

Immediately after their harvesting, amaranth stems had to be dried $\left(50{ }^{\circ} \mathrm{C}, 48 \mathrm{~h}\right)$ to facilitate their storage over time. Their structure was then manually studied from ten specimens. They were composed of a light pith fraction in their middle $(24 \%(w / w))$, and a bark one, fibrous and rigid, in their periphery $(76 \%(w / w))$ (Figure 2a). 


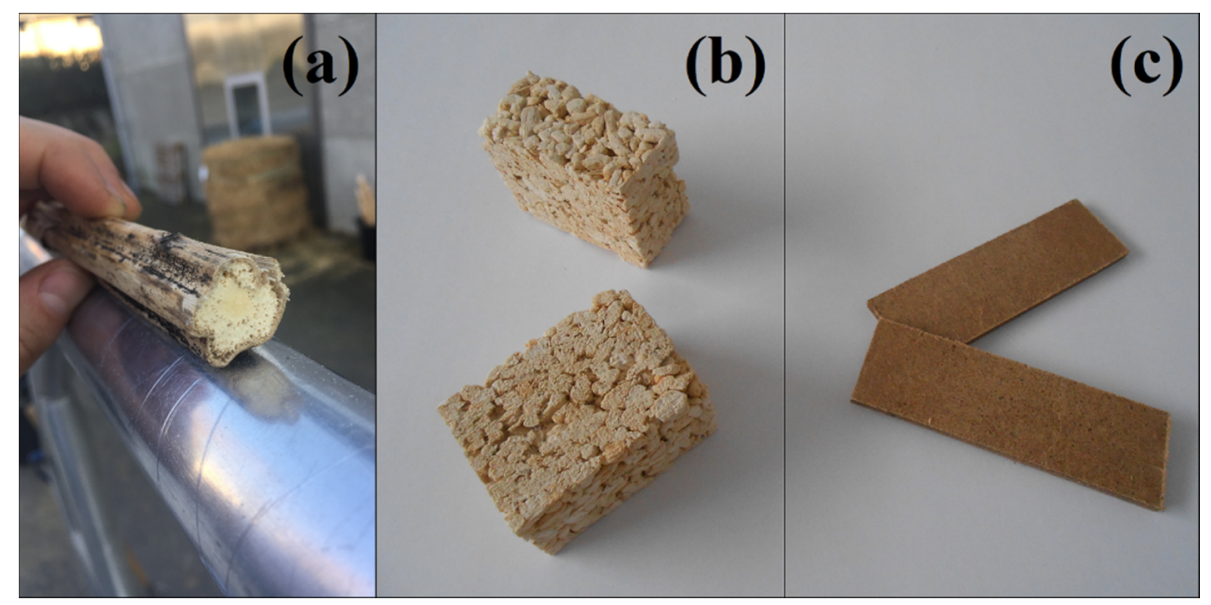

Figure 2. (a) Photograph of the amaranth stem (cross section); (b) Photograph of the optimal insulation block from the BP pith fraction; (c) Photograph of the optimal hardboard (HB6) from extrusion-refined bark.

The structure of the amaranth stem is reminiscent of sunflower or even corn. Nevertheless, the elements of the amaranth stem are not yet valorized in the field of renewable materials. Conversely, pith and bark fractions from sunflower stems have been the subject of recent work to transform them into low-density insulating blocks [22], or rigid [11] and semi-rigid [22] panels, respectively.

Based on the same principle as for sunflower, the amaranth stem fractions could therefore be used as basic elements for valorization in the materials sector. Indeed, the pith could be used as thermal insulation while the bark fraction could be used for the production of dense boards through hot pressing.

The large difference in density between bark and pith particles enabled their continuous mechanical separation through a two-stage process involving a grinding step of the stems, and then a suction one. On the one hand, the grinding step allowed the pith to be separated from the bark particles. On the other hand, during the suction step, the use of a vacuum cleaner resulted in the isolation of the lighter pith particles from those of bark. The suction operation was repeated three times, first on a vibrating sieve shaker and then twice on an inclined conveyor belt.

Table 1 shows the mass balance for each of the three suction stages based on $100 \mathrm{~kg}$ of crushed amaranth stem. For its part, Table 2 shows the evolution of the pith purity of the light fractions, sucked after the sieving step (P1) and after each passage on the conveyor belt (P2 and P3), respectively. The pith purity was measured twice by manually separating the residual bark particles from the pith ones. The pith purity was multiplied by more than four thanks to the two conveyor belt purification steps. It was greater than $90 \%(w / w)$ after the three consecutive suction steps, which was considered sufficient to produce low-density insulation blocks.

Table 1. Mass balance of the fractionation of $100 \mathrm{~kg}$ amaranth stem into bark particles and a sucked fraction containing the pith ones for the three successive suction stages, and mass of the two fractions collected at the end of the separation process.

\begin{tabular}{ccccc}
\hline Fraction & Suction Number 1 & Suction Number 2 & Suction Number 3 & $\begin{array}{c}\text { Mass Balance after } \\
\text { Suction Number 3 }\end{array}$ \\
\hline Bark particles $(\mathrm{kg})$ & 80.9 & 11.7 & 2.6 & $95.2^{1}$ \\
Pith fraction sucked out $(\mathrm{kg})^{2}$ & 19.1 & 7.4 & 4.8 & $4.8^{3}$ \\
\hline
\end{tabular}

${ }^{1}$ At the end of the fractionation process, the bark particles collected after each suction stage were mixed together to form a single fraction of bark particles. ${ }^{2}$ The pith fractions sucked out after stages number 1 and 2 constituted the input materials for the following stages, i.e., stages number 2 and 3, respectively. ${ }^{3}$ The pith fraction from stage number 3 was the fraction used in this study for the manufacture of the insulating materials. 
Table 2. Purity in pith particles of the sucked fraction after each suction stage.

\begin{tabular}{cccc}
\hline Suction Stage & Suction Number 1 & Suction Number 2 & Suction Number 3 \\
\hline $\begin{array}{c}\text { Purity in pith } \\
\text { particles }(\%(w / w))\end{array}$ & $22.9 \pm 0.1$ & $59.0 \pm 0.3$ & $91.0 \pm 0.2$ \\
\hline
\end{tabular}

\subsection{Chemical Composition of Pith and Bark, and Physical Characterization of Pith Particles}

Table 3 shows the chemical composition of the pith and bark, both from the amaranth stem. While the pith contains a median amount of lignocellulosic fibers $(47 \%)$, but a lot of minerals and water-soluble components (19\% and $31 \%$, respectively), the bark is much richer in lignocellulosic fibers (64\%), and it has much lower mineral and especially water-soluble contents. Thus, the bark is indeed the woody part (or ligneous fraction) of the stem.

Table 3. Chemical composition of pith and bark from amaranth stem (\% of the dry matter).

\begin{tabular}{ccc}
\hline Components & Pith & Bark \\
\hline Minerals & $18.9 \pm 0.2$ & $9.3 \pm 0.3$ \\
Cellulose & $37.5 \pm 0.5$ & $43.6 \pm 0.6$ \\
Hemicelluloses & $12.1 \pm 0.1$ & $17.6 \pm 0.4$ \\
Lignins & $9.4 \pm 0.2$ & $20.3 \pm 0.6$ \\
Water-soluble components & $31.2 \pm 0.2$ & $14.8 \pm 0.9$ \\
\hline
\end{tabular}

In addition to these previous comments, it should be pointed out here that the sum of the chemical compounds quantified in both pith and bark was greater than $100 \%$. This is explained by the fact that minerals in ionic form as well as some hemicelluloses, especially those with the lowest molecular weights, may be soluble in water. These chemical constituents could then be quantified twice.

Due to their alveolar structure, the pith particles were light, with an estimated bulk density of only $32.2 \mathrm{~kg} / \mathrm{m}^{3}$ (Table 4). Their particle size distribution is also presented in Table 4. Considered as dust (i.e., fines), the particles smaller than $1 \mathrm{~mm}$ have not been kept for the manufacture of the low-density insulation blocks. The other three pith fractions generated after sieving (i.e., SP, MP and BP) were also characterized in bulk density (Table 4), and the results obtained revealed significant differences.

Table 4. Particle size distribution of the amaranth pith particles, and bulk density, thermal conductivity and thermal resistance in bulk at $25^{\circ} \mathrm{C}$ of all pith particles (mix) and the SP, MP, and BP fractions generated after sieving ${ }^{1}$.

\begin{tabular}{ccccc}
\hline Pith Fraction & $\begin{array}{c}\text { Distribution }(\mathbf{\%} \\
(\boldsymbol{w} / \boldsymbol{w}) \mathbf{)}\end{array}$ & $\begin{array}{c}\text { Bulk Density } \\
\left(\mathbf{k g} / \mathbf{m}^{\mathbf{3}} \mathbf{)}\right.\end{array}$ & $\begin{array}{c}\text { Thermal } \\
\text { Conductivity } \\
(\mathbf{m W} /(\mathbf{m} . \mathbf{K}) \mathbf{)}\end{array}$ & $\begin{array}{c}\text { Thermal } \\
\text { Resistance }^{6} \\
\left.\mathbf{( m}^{\mathbf{2}} \cdot \mathbf{K} / \mathbf{W}\right)\end{array}$ \\
\hline Mix $^{2}$ & 100.0 & $32.2 \pm 1.0^{\mathrm{b}}$ & $37.0 \pm 0.0^{\mathrm{b}}$ & $1.081 \pm 0.000^{\mathrm{a}}$ \\
Fines $(<1 \mathrm{~mm})$ & 15.0 & n.d. & n.d. & n.d. \\
$\mathrm{SP}^{3}$ & 17.8 & $29.6 \pm 0.5^{\mathrm{c}}$ & $37.0 \pm 0.0^{\mathrm{b}}$ & $1.081 \pm 0.000^{\mathrm{a}}$ \\
$\mathrm{MP}^{4}$ & 41.7 & $32.0 \pm 0.2^{\mathrm{b}}$ & $39.5 \pm 0.7^{\mathrm{a}}$ & $1.013 \pm 0.018^{\mathrm{b}}$ \\
$\mathrm{BP}^{5}$ & 25.5 & $39.4 \pm 0.7^{\mathrm{a}}$ & $41.0 \pm 1.4^{\mathrm{a}}$ & $0.976 \pm 0.034^{\mathrm{b}}$ \\
\hline
\end{tabular}

${ }^{1}$ Means in the same column with the same superscript letter (a-c) are not significantly different at $p<0.05 .{ }^{2}$ All pith fractions. ${ }^{3}$ Small particles $(1-2 \mathrm{~mm}) .{ }^{4}$ Medium particles $(2-4 \mathrm{~mm}) .{ }^{5}$ Big particles $(>4 \mathrm{~mm}) .{ }^{6}$ Thermal resistance for a $4 \mathrm{~cm}$ thick bed of pith particles. n.d., non-determined.

For its part, Table 5 proposes a distribution in weight and another one in volume for the SP, MP, and BP fractions of pith particles, in proportion to the total weight or to the total volume, respectively, of the mixture made of these three pith fractions. As a reminder, these pith fractions were the three ones used to produce the low-density insulation blocks, on their own or mixed in the right weight proportions. The results in Table 5 show relatively 
close weight and volume distributions, with the intermediate pith fraction (MP particles) representing for both distributions a value close to $50 \%$, followed by the coarser fraction (BP particles) and then the fraction made up of the smallest particles (SP particles).

Table 5. Distribution in weight $(\%(w / w))$ and distribution in volume $(\%(v / v))$ for the SP, MP, and $\mathrm{BP}$ fractions of pith particles, calculated in proportion to the total weight or to the total volume, respectively, of the mixture made of these three pith fractions.

\begin{tabular}{ccc}
\hline Pith Fraction & $\begin{array}{c}\text { Distribution in Weight } \\
(\%(w / w))\end{array}$ & $\begin{array}{c}\text { Distribution in Volume } \\
(\%(v / v))\end{array}$ \\
SP & 20.9 & 23.6 \\
MP & 49.1 & 51.1 \\
BP & 30.0 & 25.3 \\
\hline
\end{tabular}

Thermal conductivity measurements were also performed on each bulk pith sample using the hot wire method. The thermal conductivity values obtained are shown in Table 4 . The results revealed that they were of the same order of magnitude as those of a commercial cellulose wadding used as bulk insulation for which the thermal conductivity at $25^{\circ} \mathrm{C}$ was between 38 and $44 \mathrm{~mW} /(\mathrm{m} . \mathrm{K})$.

\subsection{Low-Density Insulation Blocks from Pith}

Low-density insulation blocks were produced from pith particles through compression molding using standard conditions already implemented in a previous study [20], i.e., $9 \mathrm{kPa}$ for the applied pressure, $5 \mathrm{~min}$ for the molding time, and $25^{\circ} \mathrm{C}$ for the mold temperature. Once molded, all blocks were placed in a ventilated oven to evaporate the water initially added to dissolve the starchy binder. The adhesion was achieved after complete evaporation, and all the resulting blocks were cohesive enough to be machined.

Blocks having a $10 \%(w / w)$ binder content were produced from the three sieved fractions and from the mix made of all pith particles. In addition to these four insulating materials, three other low-density blocks made from the medium pith particles (MP) were also molded using higher binder contents, i.e., $15 \%, 20 \%$, and $25 \%(w / w)$, respectively. All the characteristics of these seven low-density insulation blocks are presented in Table 6 . These include density, flexural properties, thermal conductivity, and thermal resistance.

Table 6. Characteristics of the low-density insulation blocks produced from pith particles through compression molding $\left(9 \mathrm{kPa}, 5 \mathrm{~min}, 25^{\circ} \mathrm{C}\right)^{1}$.

\begin{tabular}{|c|c|c|c|c|c|c|}
\hline Pith Particles & $\begin{array}{c}\text { Binder } \\
\text { Content }(\%)\end{array}$ & $\begin{array}{l}\text { Density } \\
\left(\mathrm{kg} / \mathrm{m}^{3}\right)\end{array}$ & $\begin{array}{c}\text { Flexural } \\
\text { Strength (kPa) }\end{array}$ & $\begin{array}{c}\text { Elastic } \\
\text { Modulus (kPa) }\end{array}$ & $\begin{array}{c}\text { Thermal } \\
\text { Conductivity } \\
(\mathrm{mW} /(\mathrm{m} . \mathrm{K}))\end{array}$ & $\begin{array}{c}\text { Thermal } \\
\text { Resistance }{ }^{2} \\
\left(\mathrm{~m}^{2} \cdot \mathrm{K} / \mathrm{W}\right)\end{array}$ \\
\hline Mix & 10 & $131.4 \pm 2.4^{\mathrm{a}}$ & $59.3 \pm 4.5^{b}$ & $510 \pm 29^{c}$ & $60.3 \pm 1.5^{\mathrm{a}}$ & $0.664 \pm 0.017^{\mathrm{d}}$ \\
\hline SP & 10 & $115.8 \pm 2.2^{c}$ & $15.8 \pm 1.9^{\mathrm{f}}$ & $169 \pm 21^{g}$ & $57.5 \pm 0.6^{b}$ & $0.696 \pm 0.007^{c}$ \\
\hline MP & 10 & $102.4 \pm 5.9^{\mathrm{e}}$ & $23.0 \pm 3.4^{\mathrm{e}}$ & $299 \pm 44^{f}$ & $54.8 \pm 1.5^{\mathrm{d}}$ & $0.731 \pm 0.020^{a}$ \\
\hline MP & 15 & $108.1 \pm 1.9^{d}$ & $29.5 \pm 4.5^{\mathrm{d}}$ & $343 \pm 40^{\mathrm{e}}$ & $54.8 \pm 0.5^{\mathrm{d}}$ & $0.731 \pm 0.007^{a}$ \\
\hline MP & 20 & $128.9 \pm 3.9^{a}$ & $45.3 \pm 3.1^{c}$ & $647 \pm 28^{a}$ & $56.5 \pm 1.3^{b c}$ & $0.708 \pm 0.016^{b c}$ \\
\hline MP & 25 & $130.9 \pm 1.5^{\mathrm{a}}$ & $44.7 \pm 5.9^{c}$ & $582 \pm 15^{b}$ & $60.3 \pm 0.5^{\mathrm{a}}$ & $0.664 \pm 0.006^{d}$ \\
\hline $\mathrm{BP}$ & 10 & $120.7 \pm 1.7^{b}$ & $84.5 \pm 8.2^{\mathrm{a}}$ & $468 \pm 17^{\mathrm{d}}$ & $56.0 \pm 1.4^{c}$ & $0.715 \pm 0.018^{b c}$ \\
\hline
\end{tabular}

${ }^{1}$ Means in the same column with the same superscript letter (a-g) are not significantly different at $p<0.05 .{ }^{2}$ Thermal resistance for a 4-cm thick low-density insulation block.

\subsection{Twin-Screw Extrusion-Refining of Bark}

During the twin-screw extrusion-refining pre-treatment, the amaranth bark undergoes defibring (i.e., destructuring) due to the mechanical stresses and temperature in the extruder. Three different inlet flow rates of water were tested in this study, i.e., $10 \mathrm{~kg} / \mathrm{h}$, $20 \mathrm{~kg} / \mathrm{h}$, and $40 \mathrm{~kg} / \mathrm{h}$, respectively, thus corresponding to liquid/solid ratios varying from 
1.0 to 4.0. The results of the amaranth bark refining treatment in twin-screw extruder are shown in Table 7. As a first result of this treatment, the three extrudates obtained had the form of fluffy materials, with significantly reduced apparent and tapped densities compared to those of the simply ground bark particles (i.e., $147.7 \pm 1.3 \mathrm{~kg} / \mathrm{m}^{3}$ and $148.5 \pm 4.2 \mathrm{~kg} / \mathrm{m}^{3}$, respectively).

Table 7. Inlet flow rate of water, liquid/solid ratio, outlet flow rate of the filtrate, content of watersoluble components in the filtrate, extraction yield in water-soluble components, and apparent and tapped densities of the extrudate after drying for the three twin-screw extrusion-refining experiments applied to the amaranth bark particles $\left(10 \mathrm{~kg} / \mathrm{h}\right.$ for their inlet flow rate) ${ }^{1}$.

\begin{tabular}{|c|c|c|c|}
\hline Experiment Number & 1 & 2 & 3 \\
\hline Inlet flow rate of water $(\mathrm{kg} / \mathrm{h})$ & 10 & 20 & 40 \\
\hline Liquid/solid ratio & 1 & 2 & 4 \\
\hline Outlet flow rate of the extrudate $(\mathrm{kg} / \mathrm{h})$ & 13.2 & 13.9 & 13.7 \\
\hline Moisture in the extrudate $(\%)$ & $28.6 \pm 0.6^{\mathrm{c}}$ & $37.6 \pm 0.3^{b}$ & $38.2 \pm 0.1^{\mathrm{a}}$ \\
\hline $\begin{array}{l}\text { Water-solubles in the extrudate } \\
\text { (\% of the dry matter) }\end{array}$ & $13.1 \pm 0.1^{\mathrm{a}}$ & $10.8 \pm 0.6^{b}$ & $7.5 \pm 0.1^{\mathrm{c}}$ \\
\hline Outlet flow rate of the filtrate $(\mathrm{kg} / \mathrm{h})$ & 0.1 & 12.7 & 29.7 \\
\hline Dry matter in the filtrate $(\%)$ & $1.1 \pm 0.0^{\mathrm{c}}$ & $5.9 \pm 0.1^{\mathrm{a}}$ & $3.2 \pm 0.3^{b}$ \\
\hline Water evaporated $(\%)^{2}$ & 67.0 & 17.0 & 16.7 \\
\hline Extraction yield in water-solubles (\%) & 11.7 & 32.9 & 54.2 \\
\hline Apparent density of extrudate $\left(\mathrm{kg} / \mathrm{m}^{3}\right)$ & $63.3 \pm 1.6^{b}$ & $69.9 \pm 2.0^{\mathrm{a}}$ & $63.5 \pm 0.6^{b}$ \\
\hline Tapped density of extrudate $\left(\mathrm{kg} / \mathrm{m}^{3}\right)$ & $70.6 \pm 1.3^{b}$ & $74.5 \pm 1.9^{\mathrm{a}}$ & $71.7 \pm 1.3^{\mathrm{b}}$ \\
\hline
\end{tabular}

${ }^{1}$ Means in the same line with the same superscript letter (a-c) are not significantly different at $p<0.05 .{ }^{2}$ The difference between the cumulative inlet flow rate (bark particles plus water) and the cumulative outlet one (extrudate plus filtrate) can be explained by the loss of part of the added water by evaporation, at the level of the filtration module and at the outlet of the barrel.

When the quantity of water increased, this facilitated the transport of the solid material whose residence time in the twin-screw extruder decreased. Thus, the extrudate obtained has undergone less shearing, and its fiber length was therefore better preserved. This was previously evidenced in the case of rice straw [27], and the same was true in this study. Nonetheless, the values obtained for both apparent and tapped densities of the extrusionrefined fibers remained in the same order of magnitude for the three tested liquid/solid ratios.

Looking at the content in water-solubles remaining in the extrudate, the values obtained were all three significantly different. With a higher liquid/solid ratio, the flow rate of the filtrate collected at the penultimate module increased, also bringing with it more water-soluble components initially present in the bark. The extrudate obtained from the higher liquid/solid ratio (i.e., 4.0) was therefore more depleted in water-soluble components. From the extrusion-refining data in Table 7, the flow rate of water-soluble compounds extracted from the bark and contained in the filtrate could be calculated. These extracted water-soluble compounds were then expressed as a percentage of the incoming water-solubles in bark, for the three liquid/solid ratios tested (i.e., 1.0, 2.0 and 4.0). The results were $11.7 \%, 32.9 \%$, and $54.2 \%$, respectively. It was therefore well observed that the extraction yield in water-soluble components increased with the amount of water added.

To conclude, although three liquid/solid ratios have been tested in the twin-screw extruder, only the extrudate produced using the liquid/solid ratio of 4.0 has been used in the production of hardboards through hot pressing. Indeed, due to the higher amount of water added during the thermo-mechanical defibration of the amaranth bark particles in the twin-screw extruder, the length of the fiber bundles was better preserved.

\subsection{Hardboards from Bark}

Hardboards were produced through hot pressing from ground (GB) or extrusionrefined (ERB) amaranth bark particles. The molding conditions used were as follows: 
$200{ }^{\circ} \mathrm{C}$ for the mold temperature, $20 \mathrm{MPa}$ for the applied pressure, and $5 \mathrm{~min}$ for the molding time. In particular, the $200{ }^{\circ} \mathrm{C}$ mold temperature was used as optimal temperature to ensure an efficient mobilization of the internal binders inside bark, i.e., free sugars, hemicelluloses and lignins $[13,30]$. Thanks to the adhesive ability of these chemicals, cohesive hardboards were obtained without exogenous binder.

An improvement in the molding process consisted in adding to the bark particles an amaranth-based binder (AB). This exogenous binder had the form of grinded and deoiled amaranth seeds, and it was the starch and to a lesser extent, proteins contained in $\mathrm{AB}$ that have given it its aptitude for adhesion.

All the characteristics of the six hardboards produced (HB1 to HB6) are presented in Table 8. These include density, flexural properties and water resistance. In addition, these characteristics were also compared in Table 8 with those of two commercial woodbased materials, i.e., MDF and chipboard (CH).

Table 8. Density, flexural properties, and water resistance of hardboards (HB) produced from ground and extrusionrefined barks (GB and ERB, respectively) through hot pressing $\left(200^{\circ} \mathrm{C}\right.$ mold temperature, $20 \mathrm{MPa}$ applied pressure, and 5 min molding time) ${ }^{1}$, and comparison with the properties of two commercial wood-based materials (i.e., MDF and chipboard $(\mathrm{CH})$ ).

\begin{tabular}{|c|c|c|c|c|c|c|c|}
\hline $\begin{array}{l}\text { Hardboard } \\
\text { Number }\end{array}$ & $\begin{array}{l}\text { Bark } \\
\text { Form }\end{array}$ & AB (\%) & $\begin{array}{l}\text { Density } \\
\left(\mathrm{kg} / \mathrm{m}^{3}\right)\end{array}$ & $\begin{array}{c}\text { Flexural } \\
\text { Strength (MPa) }\end{array}$ & $\begin{array}{l}\text { Elastic Modulus } \\
\text { (GPa) }\end{array}$ & $\begin{array}{c}\text { Thickness } \\
\text { Swelling (\%) }\end{array}$ & $\begin{array}{c}\text { Water } \\
\text { Absorption (\%) }\end{array}$ \\
\hline HB1 & GB & 0 & $1234 \pm 28^{a}$ & $13.2 \pm 2.4^{\mathrm{d}}$ & $2.1 \pm 0.4^{\mathrm{d}}$ & $143 \pm 11^{a}$ & $124 \pm 8^{a}$ \\
\hline HB2 & GB & 20 & $1248 \pm 34^{\mathrm{a}}$ & $18.8 \pm 1.7^{\mathrm{c}}$ & $2.7 \pm 0.4^{b c}$ & $136 \pm 10^{a}$ & $124 \pm 7^{\mathrm{a}}$ \\
\hline HB3 & GB & 40 & $1242 \pm 31^{\mathrm{a}}$ & $18.5 \pm 2.3^{c}$ & $2.1 \pm 0.4^{\mathrm{d}}$ & $132 \pm 20^{a}$ & $132 \pm 11^{\mathrm{a}}$ \\
\hline HB4 & ERB & 0 & $1244 \pm 35^{\mathrm{a}}$ & $19.8 \pm 1.6^{c}$ & $2.4 \pm 0.2^{\mathrm{cd}}$ & $71 \pm 4^{b}$ & $56 \pm 2^{b}$ \\
\hline HB5 & ERB & 10 & $1279 \pm 47^{\mathrm{a}}$ & $32.4 \pm 2.6^{b}$ & $2.9 \pm 0.3^{b}$ & $77 \pm 4^{b}$ & $60 \pm 1^{b}$ \\
\hline HB6 & ERB & 20 & $1318 \pm 47^{\mathrm{a}}$ & $35.8 \pm 2.9^{a}$ & $4.2 \pm 0.2^{\mathrm{a}}$ & $87 \pm 5^{b}$ & $69 \pm 2^{b}$ \\
\hline MDF [29] & - & - & $589 \pm 4$ & $20.7 \pm 2.1$ & $1.5 \pm 0.1$ & $20 \pm 1$ & $51 \pm 5$ \\
\hline $\mathrm{CH}$ [29] & - & - & $710 \pm 7$ & $10.2 \pm 1.5$ & $1.4 \pm 0.1$ & $25 \pm 1$ & $58 \pm 3$ \\
\hline
\end{tabular}

${ }^{1}$ Means in the same column with the same superscript letter (a-d) are not significantly different at $p<0.05$.

\section{Discussion}

\subsection{Physical Characterization of Pith Particles}

Once isolated, pith particles were sieved, resulting in the next particle size distribution: $18 \%$ for small particles (SP) (from 1 to $2 \mathrm{~mm}$ ), $42 \%$ for medium particles (MP) (from 2 to $4 \mathrm{~mm}$ ), and $25 \%$ for big particles (BP) (>4 mm) (Table 4). Fines $(<1 \mathrm{~mm})$ represented $15 \%$ $(w / w)$ but they were not used in the present study. All pith particles revealed an alveolar structure, and this resulted in low bulk densities, e.g., only $30 \mathrm{~kg} / \mathrm{m}^{3}$ for the smaller particle size (SP).

Despite the fact that small pith particles had fewer inter-particle voids, due to a better arrangement (i.e., stacking) of the particles in relation to each other, it was these smaller particles (SP) that revealed the lowest bulk density value (Table 4). This could be explained by the fact that the larger ones (BP) and, to a lesser extent, the medium ones (MP) still contained some long fibers from the bark fraction after the sieving step of the pith particles. For the BP fraction, the decrease in bulk density that should have been observed due to more inter-particle voids was therefore largely compensated by the presence of these denser bark fibers, which contributed to increase the density of the BP pith fraction. Conversely, the smaller particles were too small to contain residual bark fibers after sieving.

As seen previously with bulk density, the thermal conductivity at $25^{\circ} \mathrm{C}$ of the bulk pith therefore also increased with the particle size, with the residual bark particles present in the BP fraction being denser and above all more conductive than the pith particles (Table 4).

The amaranth pith thus appears as a promising bulk raw material for the thermal insulation of buildings, as previously observed for sunflower pith [20,22]. This makes it possible to position the pith or one of its sieved fractions, especially the smaller one (i.e., the SP fraction) for which the thermal conductivity and thermal resistance are significantly 
different from the two others, in the building insulation market. For example, it could be blown into the attic of houses or used as a filling for the interior partitions. However, it remains to be seen how the pith particles will behave over time. If the pith is compacted, it could become denser over the years and its thermal conductivity will increase. In the same way, for long-term use, it will also be necessary to judge the pith's behaviour to fire and its ability to resist fungi.

For future work, the coating of the pith particles by a hydrophobing agent (e.g., hydrogenated oils, vegetable oil derivatives, etc.) and a fireproofing product would improve their water and fire resistances, respectively. In the same way, glycerol esters could be a bio-based solution favourable to render the pith particles more resistant to microbial growth when coated at their surface [22].

\subsection{Low-Density Insulation Blocks from Pith}

Cohesive low-density insulation blocks were produced through compression molding thanks to the addition of the starchy binder. A progressive increase in the density of the blocks made of MP particles was observed with the binder content (Table 6). In parallel, the bending performance of the blocks improved since a larger binder quantity allowed the pith particles to be better impregnated with the starchy glue. Logically, the overall cohesion of the block was thus progressively improved. However, this densification resulted in a lower internal porosity inside the blocks, which then had a higher and higher thermal conductivity and therefore a lower and lower thermal resistance.

As the MP-based blocks remained machinable even with only $10 \%(w / w)$ binder, this content was retained for the other pith fractions (Figure 3) since it was expected to give to the insulating blocks a better thermal insulation performance. For such binder content added, the densest and most conductive insulating block was the one made from the mix of pith particles, which could be explained by the fact that this fraction still contained about $9 \%(w / w)$ of bark impurities (Table 2). For the blocks made from the sieved fractions, the values obtained for the density and thermal conductivity were significantly different. A significant reduction in the density and thermal conductivity was observed with increasing particle size when comparing the materials made from the SP and MP fractions, respectively. The most likely reason for such a result was the presence of more inter-particle voids in the case of the block made from the medium size particles. Conversely, and as it was already observed for the bulk pith particles, a significant increase in the density and, to a lesser extent, in thermal conductivity was obtained for the block made from the bigger particles. This was evidently due to the substantial amount of dense bark impurities remaining inside the BP fraction after sieving.

For this $10 \%(w / w)$ binder content, the flexural performance of the insulating blocks made from the sieved fractions revealed significant differences, and it increased with the size of the pith particles used. Indeed, the larger the particles were, the smaller was their cumulative surface area. Thus, with the pith particles from the BP fraction, more starch-based adhesive was present on their surface, which resulted in a better bonding of the particles to each other and therefore better mechanical performance in bending of the corresponding block. The flexural strength of the block originating from the mix of all the pith particles was also significantly different and logically median, i.e., situated between those of the MP and BP-based blocks.

For the optimal $10 \%(w / w)$ binder content, the best compromise between flexural and heat insulation properties was obtained using big particles $(>4 \mathrm{~mm})$ (Table 6). Light and insulating, this optimal BP-based block (Figures $2 \mathrm{~b}$ and $3 \mathrm{~b}$ ) especially preserved very good machinability, and it could thus be positioned at all levels of the buildings, e.g., walls, floors, roofs, etc. However, its thermal conductivity at $25^{\circ} \mathrm{C}(56 \mathrm{~mW} /(\mathrm{m} . \mathrm{K}))$ was higher to those of sunflower-based insulation panels $[20,22]$ and especially commercial expanded polystyrene [20]: $38-41 \mathrm{~mW} /(\mathrm{m} . \mathrm{K})$ and only $32 \mathrm{~mW} /(\mathrm{m} . \mathrm{K})$, respectively. These results made it a slightly less efficient insulator than the two other materials mentioned above. Indeed, based on the thermal resistance of these three types of insulating materials, 
defined as the ratio of the material thickness to its thermal conductivity, the thickness of the amaranth-based optimal block should be increased by $37-47 \%$ or by up to $75 \%$, respectively, to reach the same thermal insulating capacity as sunflower-based low-density blocks or polystyrene.

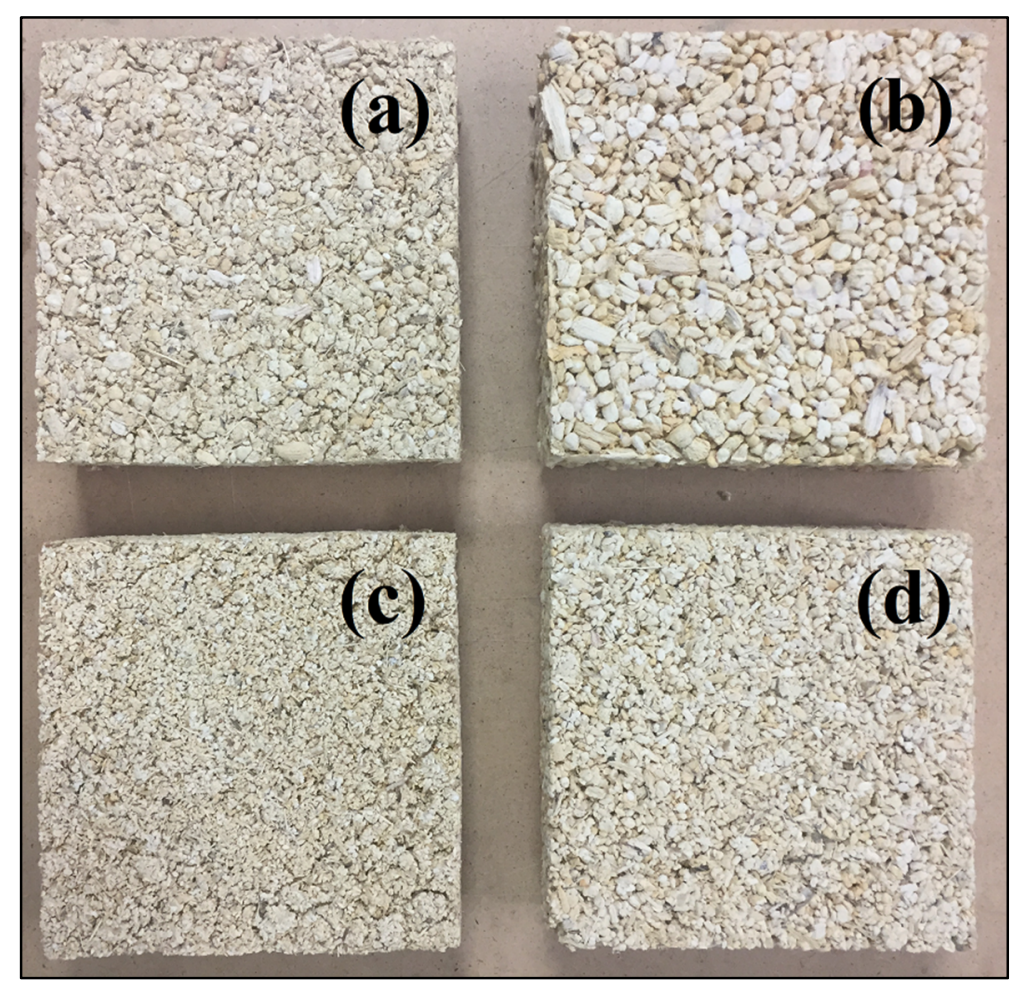

Figure 3. (a) Photograph of the low-density insulation block made from the MP sieved fraction of pith particles; (b) Photograph of the low-density insulation block made from the BP sieved fraction of pith particles; (c) Photograph of the low-density insulation block made from the SP sieved fraction of pith particles; (d) Photograph of the low-density insulation block made from the mix of the SP, MP, and BP pith particles. All the insulation blocks have a $10 \%(w / w)$ starchy binder content.

However, these results are only preliminary, and some improvements are still possible. On the one hand, a better purification of the BP pith particles, which would then contain a lower proportion of bark impurities, should lead to a reduction in the thermal conductivity of the obtained insulating block. On the other hand, an adaptation of the compression molding conditions should also improve the insulating capacity of the amaranth-based block. For future work, its water vapor permeability will also have to be determined. As for the low-density blocks made from sunflower pith [20,22], it should be quite high, which could also make this insulating material a promising water regulator.

As for the pith particles used in bulk, additional developments will also be required to improve the durability of the optimal low-density insulation block before proposing it to the market. A reduction in its water sensitivity could be achieved thanks to the replacement of the starchy binder by another polysaccharide binder with physical curing, e.g., alginates and especially Citrus pectins and chitosan [50]. It could be also achieved thanks to its coating by hydrophobing agents even if its ability as a water regulator may be partially impaired after such post-treatment. The addition of a fireproofing product to the formulation would also render the amaranth-based block more resistant to fire. Lastly, glycerol esters appear as a promising renewable solution to protect it against microbial growth [22]. 


\subsection{Hardboards from Bark}

The high lignocellulose content for bark ( $43.6 \%$ cellulose, $17.6 \%$ hemicelluloses, and $20.3 \%$ lignins) contributed to its potential for producing hardboards (HB), i.e., dense fiberboards, through hot pressing. Cohesive hardboards were obtained with no external binder added (HB1 and HB4) (Table 8), due to the adhesive ability of some chemicals inside bark (i.e., free sugars, hemicelluloses, and lignins). Both HB1 and HB4 boards could thus be considered as promising binderless fiberboards.

Especially, the HB4 hardboard obtained from a previously extrusion-refined bark (ERB), using water at a 4 liquid/solid ratio, was much more mechanically resistant $(+50 \%$ for flexural strength) than that from ground bark (GB). This was already observed for coriander straw [13], and for shives from oleaginous flax [30]. The extrusion-refining pretreatment contributed to a much more favorable fiber morphology (large increase in their mean aspect ratio), just as to an efficient separation between cellulose, hemicelluloses, and lignins inside the extruded material, thus facilitating the mobilization of internal binders during hot pressing.

An additional improvement in the bending properties was obtained by adding to the bark grinded and deoiled amaranth seeds. Here, because of its richness in proteins and especially starch, this $\mathrm{AB}$ amaranth-based binder was used as a natural external binder, and its binding ability was evidenced for the ground bark, just as for the extrusion-refined one. In addition, especially for the ERB fibrous reinforcement, the more the amaranth-based binder added, the more the flexural strength and the more the elastic modulus. The best flexural properties were obtained when adding $20 \%$ AB to ERB (Table 8). Such amount of $\mathrm{AB}$ added allowed the ERB fibers to stick well together.

From the point of view of sensitivity to water of the hardboards produced, using the extrusion-refined bark divided the thickness swelling and water absorption values by up to 2 for a panel without exogenous binder, and by up to 1.5 for a panel hot pressed with $20 \%$ amaranth-based binder added (Table 8 ). The interest of the preliminary defibration of the amaranth bark in a twin-screw extruder regarding the water resistance of the obtained panels is thus indisputable.

The optimal hardboard (HB6) (Figure 2) has a $36 \mathrm{MPa}$ flexural strength, which is significantly different from all the other strength values in the present study. This value is also $23 \%$ higher than that of another fiberboard recently developed from coriander (29 MPa) [13]. It is also much higher than the flexural strengths of two commercial woodbased materials tested in a previous study [29], i.e., MDF and chipboard: $73 \%$ and up to $251 \%$, respectively (Table 8 ). HB6 board is thus undoubtedly a viable, sustainable alternative for replacing current building wood-based materials like plywood, chipboard, OSB, MDF, etc. According to the NF EN 312 standard [51], it is already usable for interior fittings (including furniture) in a dry environment (P2 type board). In addition to furniture, its possible uses in buildings include interior partitions, underlays for floors, panels for suspended ceilings, etc. However, its fire resistance will have to be characterized before using it inside houses. The addition of a flame retardant to the formulation prior to hot pressing may be considered in the event of poor fire resistance.

The optimal board nevertheless reveals a greater sensitivity to water after $24 \mathrm{~h}$ immersion than commercial MDF or chipboard type panels (Table 8). With much improved water resistance (10\% max thickness swelling), it could also be used as a P7 type board, i.e., a board working under high stress, used in humid environment. For future work, multiple solutions could be investigated to improve the water resistance. Firstly, a reduction in thickness swelling could be attained thanks to a heat post-treatment. This was already evidenced for two types of renewable fiberboards, i.e., one made of coriander straw as reinforcement and press cake from seeds as binder [13], and another made of oleaginous flax shives as reinforcement and plasticized linseed cake as binder [31]. At the end of this post-treatment, an increase in the flexural strength was even observed at the same time as the reduction in thickness swelling for these two innovative materials. 
In order to meet the same objective of increasing water resistance, other treatments may be tested after hot pressing, e.g., coating, chemical, or steam treatment [30]. In particular, the application of a coating based on vegetable oils or their derivatives could be a promising renewable solution to improve the stability in the board dimension after soaking in water. Among these bio-sourced additives, drying oils such as linseed oil or hydrogenated oils that have the property of being solid at room temperature appear to be good candidates.

For future industrial process intensification, one single extruder pass would allow the continuous production of a premix ready to be molded through hot pressing, and associating the refined fibers from amaranth bark as mechanical reinforcement, the amaranth-based binder and even water-repellent and/or flame-retardant additives [31]. Indeed, in addition to its ability evidenced in this study to refine plant fibers, the twin-screw extrusion technology is also known for its particularly intense mixing ability $[25,26]$. From the same machine, the amaranth bark could thus be extrusion-refined in the presence of water in the first half of the screw profile. Then, the deoiled amaranth seeds and any additives could be added in its middle thanks to a side feeder. Finally, the second half of the screw profile could be used for the intimate mixing of all these components with each other. Using the as-described combined process, the premix would be produced at a reduced cost before being transformed into hardboards.

\section{Conclusions}

In this study, the amaranth stem was used to develop innovative building materials. Representing up to $80 \%(w / w)$ of the plant aerial part, the stem is made of a pith in its middle and a bark on its periphery. Firstly, a fractionation process of the stem into these two different fractions was proposed. Secondly, bio-sourced composite materials were manufactured, i.e., thermal insulating materials made from pith (in bulk or in the form of low-density cohesive blocks), and hardboards from bark. All these materials are viable alternatives to some of the commercial materials nowadays used in buildings.

For future work, the scaling-up of the fractionation process of the amaranth stems into pith and bark fractions will be an important step for its subsequent use at an industrial scale. It should allow a better profitability of this crucial step for the process. Additional developments will also have to be conducted to improve the global performance of the amaranth-based buildings materials. In particular, various post-treatments (e.g., coating, cooking, etc.) should reduce their water sensitivity on the one hand and improve their resistance to microbial growth on the other hand. The evaluation of their fire resistance and, if necessary, the addition of fireproofing products should also be considered before they are used inside houses. Lastly, as it is expected that the low-density insulation blocks from pith will be promising water regulators, their water vapour permeability will also have to be determined. All these developments will undoubtedly facilitate the subsequent introduction of these different bio-sourced building materials on the market.

Author Contributions: Conceptualization, P.E.; methodology, P.E. and L.L.; validation, P.E., O.M., and T.T.; formal analysis, P.E. and O.M.; investigation, G.d.L. and L.L.; resources, S.B. and T.V.; writing-original draft preparation, P.E. and G.d.L.; writing-review and editing, P.E. and O.M.; supervision, P.E.; project administration, P.E. All authors have read and agreed to the published version of the manuscript.

Funding: This research received no external funding.

Institutional Review Board Statement: Not Applicable.

Informed Consent Statement: Not Applicable.

Data Availability Statement: Data sharing is not applicable.

Conflicts of Interest: The authors declare no conflict of interest. 


\section{References}

1. Kachiguma, N.K.; Mwase, W.; Maliro, M.; Damaliphetsa, A. Chemical and mineral composition of amaranth (Amaranthus L.) species collected from central Malawi. J. Food Res. 2015, 4, 92-102. [CrossRef]

2. Ogrodowska, D.; Zadernowski, R.; Czaplicki, S.; Derewiaka, D.; Wronowska, B. Amaranth seeds and products-The source of bioactive compounds. Pol. J. Food Nutr. Sci. 2014, 64, 165-170. [CrossRef]

3. Rastogi, A.; Shukla, S. Amaranth: A new millennium crop of nutraceutical values. Crit. Rev. Food Sci. Nutr. 2013, 53, 109-125. [CrossRef] [PubMed]

4. León-Camacho, M.; Garcia-González, D.L.; Aparicio, R. A detailed and comprehensive study of amaranth (Amaranthus cruentus L.) oil fatty profile. Eur. Food Res. Technol. 2001, 213, 349-355. [CrossRef]

5. Ott, C.; Lacatusu, I.; Badea, G.; Grafu, I.A.; Istrati, D.; Babeanu, N.; Stan, R.; Badea, N.; Meghea, A. Exploitation of amaranth oil fractions enriched in squalene for dual delivery of hydrophilic and lipophilic actives. Ind. Crop. Prod. 2015, 77, 342-352. [CrossRef]

6. Huang, Z.R.; Lin, Y.K.; Fang, J.Y. Biological and pharmacological activities of squalene and related compounds: Potential uses in cosmetic dermatology. Molecules 2009, 14, 540-554. [CrossRef]

7. Lidgate, D.M.; Byars, N.E. Development of an emulsion-based muramyl dipeptide adjuvant formulation for vaccines. In Vaccine Design, the Subunit and Adjuvant Approach; Powell, M.F., Newman, M.J., Eds.; Springer Nature: Lausanne, Switzerland, 1995; pp. 313-324.

8. Sayed Ahmad, B. Étude de l'agroraffinage des graines d'Apiaceae, Lamiaceae et Chenopodiaceae pour la production de molécules bio-Sourcées en vue d'application en industrie cosmétique. Ph.D. Thesis, Institut National Polytechnique de Toulouse, Université de Toulouse, Toulouse, France, 2018.

9. Caselato-Sousa, V.M.; Amaya-Farfán, J. State of knowledge on amaranth grain: A comprehensive review. J. Food Sci. 2012, 77, 93-104. [CrossRef]

10. Evon, P.; Vandenbossche, V.; Labonne, L.; Vinet, J.; Pontalier, P.Y.; Rigal, L. The thermo-mechano-chemical twin-screw reactor, a new perspective for the biorefinery of sunflower whole plant: Aqueous extraction of oil and other biopolymers, and production of biodegradable fiberboards from solid raffinate. Oilseeds Fats Crop. Lipids 2016, 23, D505. [CrossRef]

11. Evon, P.; Amalia Kartika, I.; Rigal, L. New renewable and biodegradable particleboards from jatropha press cakes. J. Renew. Mater. 2014, 2, 52-65. [CrossRef]

12. Evon, P.; Vinet, J.; Labonne, L.; Rigal, L. Influence of thermo-pressing conditions on mechanical properties of biodegradable fiberboards made from a deoiled sunflower cake. Ind. Crop. Prod. 2015, 65, 117-126. [CrossRef]

13. Uitterhaegen, E.; Labonne, L.; Merah, O.; Talou, T.; Ballas, S.; Véronèse, T.; Evon, P. Impact of thermomechanical fiber pretreatment using twin-screw extrusion on the production and properties of renewable binderless coriander fiberboards. Int. J. Mol. Sci. 2017, 18, 1539. [CrossRef] [PubMed]

14. Chabrat, E.; Abdillahi, H.; Rouilly, A.; Rigal, L. Influence of citric acid and water on thermoplastic wheat flour/poly(lactic acid) blends. I: Thermal, mechanical and morphological properties. Ind. Crop. Prod. 2012, 37, 238-246. [CrossRef]

15. Abdillahi, H.; Chabrat, E.; Rouilly, A.; Rigal, L. Influence of citric acid on thermoplastic wheat flour/poly(lactic acid) blends. II. Barrier properties and water vapor sorption isotherms. Ind. Crop. Prod. 2013, 50, 104-111. [CrossRef]

16. Samal, S.; Stuchlík, M.; Petrikova, I. Thermal behavior of flax and jute reinforced in matrix acrylic composite. J. Anal. Calorim. 2018, 131, 1035-1040. [CrossRef]

17. Maréchal, V.; Rigal, L. Characterization of by-products of sunflower culture: Commercial applications for stalks and heads. Ind. Crop. Prod. 1999, 10, 185-200. [CrossRef]

18. Vandenbossche, V.; Rigal, L.; Saiah, R.; Perrin, B. New agro-materials with thermal insulation properties. In Proceedings of the 18th International Sunflower Conference, Mar del Plata, Argentina, 27 February-1 March 2012; pp. 949-954.

19. Mati-Baouche, N.; de Baynast, H.; Lebert, A.; Sun, S.; Lopez-Mingo, C.J.S.; Leclaire, P.; Michaud, P. Mechanical, thermal and acoustical characterizations of an insulating bio-based composite made from sunflower stalks particles and chitosan. Ind. Crop. Prod. 2014, 58, 244-250. [CrossRef]

20. Sabathier, V.; Ahmed Maaloum, A.; Magniont, C.; Evon, P.; Labonne, L. Développement d'un panneau isolant $100 \%$ biosourcé à base de moelle de tournesol. In Proceedings of the National Congress of Research in IUT (CNRIUT'2017), Auxerre, France, 4-5 June 2017.

21. Buyle-Bodin, F.; Blanpain, O. Analyse du cycle de vie des ouvrages en béton. In Annales du Bâtiment et des Travaux Publics, 6th ed.; Editions ESKA: Paris, France, 2002; pp. 47-54.

22. Verdier, T.; Balthazard, L.; Montibus, M.; Magniont, C.; Evon, P.; Bertron, A. Using glycerol esters to prevent microbial growth on sunflower-based insulation panels. Proc. Inst. Civ. Eng. Constr. Mater. 2020. [CrossRef]

23. Gamon, G.; Evon, P.; Rigal, L. Twin-screw extrusion impact on natural fibre morphology and material properties in poly(lactic acid) based biocomposites. Ind. Crop. Prod. 2013, 46, 173-185. [CrossRef]

24. Uitterhaegen, E.; Parinet, J.; Mérian, T.; Ballas, S.; Véronèse, T.; Merah, O.; Talou, T.; Labonne, L.; Stevens, C.V.; Chabert, F.; et al. Performance, durability and recycling of thermoplastic biocomposites reinforced with coriander straw. Compos. Part A Appl. Sci. Manuf. 2018, 113, 254-263. [CrossRef] 
25. Evon, P.; Vandenbossche, V.; Candy, L.; Pontalier, P.Y.; Rouilly, A. Twin-screw extrusion: A key technology for the biorefinery. In Biomass Extrusion and Reaction Technologies: Principles to Practices and Future Potential, 1st ed.; Ayoub, A., Lucia, L., Eds.; ACS Symposium Series, eBooks; American Chemical Society: Washington, DC, USA, 2018; Volume 1304, pp. 25-44.

26. Vandenbossche, V.; Candy, L.; Evon, P.; Rouilly, A.; Pontalier, P.Y. The twin-screw extrusion technology, an innovative technique for the green extraction of food products. In Green Food Processing Techniques: Preservation, Transformation and Extraction, 1st ed.; Chemat, F., Vorobiev, E., Eds.; Academic Press, Elsevier: London, UK, 2019; Volume 10, pp. 289-314.

27. Theng, D.; Arbat, G.; Delgado-Aguilar, M.; Ngo, B.; Labonne, L.; Evon, P.; Mutjé, P. Comparison between two different pretreatment technologies of rice straw fibers prior to fiberboard manufacturing: Twin-screw extrusion and digestion plus defibration. Ind. Crop. Prod. 2017, 107, 184-197. [CrossRef]

28. Theng, D.; Arbat, G.; Delgado-Aguilar, M.; Ngo, B.; Labonne, L.; Mutjé, P.; Evon, P. Production of fiberboards from rice straw thermo-mechanical extrudates using thermopressing: Influence of fiber morphology, water addition and lignin content. Eur. J. Wood Wood Prod. 2019, 77, 15-32. [CrossRef]

29. Simon, V.; Uitterhaegen, E.; Robillard, A.; Ballas, S.; Véronèse, T.; Vilarem, G.; Merah, O.; Talou, T.; Evon, P. VOC and carbonyl compound emissions of a fiberboard resulting from a coriander biorefinery: Comparison with two commercial wood-based building materials. Environ. Sci. Pollut. Res. Int. 2020, 27, 16121-16133. [CrossRef] [PubMed]

30. Evon, P.; Barthod-Malat, B.; Grégoire, M.; Vaca-Medina, G.; Labonne, L.; Ballas, S.; Véronèse, T.; Ouagne, P. Production of fiberboards from shives collected after continuous fiber mechanical extraction from oleaginous flax. J. Nat. Fibers 2018, 16, 1-17. [CrossRef]

31. Evon, P.; Labonne, L.; Ullah Khan, S.; Ouagne, P.; Pontalier, P.Y.; Rouilly, A. Twin-screw extrusion process to produce renewable fiberboards. J. Vis. Exp. 2021, 167, e62072. [CrossRef]

32. Zhang, D.; Zhang, A.; Xue, L. A review of preparation of binderless fiberboards and its self-bonding mechanism. Wood Sci. Technol. 2015, 49, 661-679. [CrossRef]

33. Okuda, N.; Sato, M. Manufacture and mechanical properties of binderless boards from kenaf core. J. Wood Sci. 2004, 50, 53-61. [CrossRef]

34. Velásquez, J.A.; Ferrando, F.; Salvadó, J. Binderless fiberboard from steam exploded miscanthus sinensis: The effect of a grinding process. Holz Roh. Werkst. 2002, 60, 297-302. [CrossRef]

35. Migneault, S.; Koubaa, A.; Nadji, H.; Riedl, B.; Zhang, S.Y.T.; Deng, J. Medium-density fiberboard produced using pulp and paper sludge from different pulping processes. Wood Fiber Sci. 2010, 42, 292-303.

36. Theng, D.; Arbat, G.; Delgado-Aguilar, M.; Vilaseca, F.; Ngo, B.; Mutjé, P. All-lignocellulosic fiberboard from corn biomass and cellulose nanofibers. Ind. Crop. Prod. 2015, 76, 166-173. [CrossRef]

37. Velásquez, J.A.; Ferrando, F.; Farriol, X.; Salvadó, J. Binderless fiberboard from steam exploded miscanthus sinensis. Wood Sci. Technol. 2003, 37, 269-278. [CrossRef]

38. Xu, J.; Widyorini, R.; Yamauchi, H.; Kawai, S. Development of binderless fiberboard from kenaf core. J. Wood Sci. 2006, 52, 236-243. [CrossRef]

39. Quintana, G.; Velásquez, J.; Betancourt, S.; Gañán, P. Binderless fiberboard from steam exploded banana bunch. Ind. Crop. Prod. 2009, 29, 60-66. [CrossRef]

40. Mancera, C.; El Mansouri, N.E.; Vilaseca, F.; Ferrando, F.; Salvado, J. The effect of lignin as a natural adhesive on the physicomechanical properties of Vitis vinifera fiberboards. BioResources 2011, 6, 2851-2860. [CrossRef]

41. Mancera, C.; El Mansouri, N.E.; Pelach, M.A.; Francesc, F.; Salvadó, J. Feasibility of incorporating treated lignins in fiberboards made from agricultural waste. Waste Manag. 2012, 32, 1962-1967. [CrossRef] [PubMed]

42. Felby, C.; Pedersen, L.S.; Nielsen, B.R. Enhanced auto adhesion of wood fibers using phenol oxidases. Holzforschung 1997, 51, 281-286. [CrossRef]

43. Felby, C.; Hassingboe, J.; Lund, M. Pilot-scale production of fiberboards made by laccase oxidized wood fibers: Board properties and evidence for cross-linking of lignin. Enzym. Microb. Technol. 2002, 31, 736-741. [CrossRef]

44. Felby, C.; Thygesen, L.G.; Sanadi, A.; Barsberg, S. Native lignin for bonding of fiber boards: Evaluation of bonding mechanisms in boards made from laccase-treated fibers of beech (Fagus sylvatica). Ind. Crop. Prod. 2004, 20, 181-189. [CrossRef]

45. ISO. ISO 749:1977, Oilseed Residues—Determination of Total Ash; International Organization for Standardization: Geneva, Switzerland, 1977.

46. Van Soest, P.J.; Wine, R.H. Use of detergents in the analysis of fibrous feeds. Part iv. Determination of plant cell-wall constituents. J. Assoc. Off. Agric. Chem. 1967, 50, 50-55.

47. Van Soest, P.J.; Wine, R.H. Determination of lignin and cellulose in acid-detergent fiber with permanganate. J. Assoc. Off. Agric. Chem. 1968, 51, 780-785. [CrossRef]

48. ISO. ISO 16978:2003, Wood-Based Panels—Determination of Modulus of Elasticity in Bending and of Bending Strength; International Organization for Standardization: Geneva, Switzerland, 2003.

49. ISO. ISO 16983:2003, Wood-Based Panels—Determination of Swelling in Thickness after Immersion in Water; International Organization for Standardization: Geneva, Switzerland, 2003. 
50. Ampe, C.; Labonne, L.; Magniont, C.; Laborel-Préneron, A.; Evon, P. Thermal insulation blocks made of sunflower pith particles and polysaccharide-based binders: Influence of binder type and content on their characteristics. In Proceedings of the 4th International Conference on Bio-Based Building Materials (ICBBM 2021), Barcelona, Spain, 16-18 June 2021.

51. AFNOR. NF EN 312 (2010-11), Particleboards—Specifications; Association Française de Normalisation: La Plaine Saint-Denis, France, 2010. 